\title{
O acontecer em relevo: implicações experienciais, narrativas e midiáticas
}

\author{
Cláudio Rodrigues Coração*
}

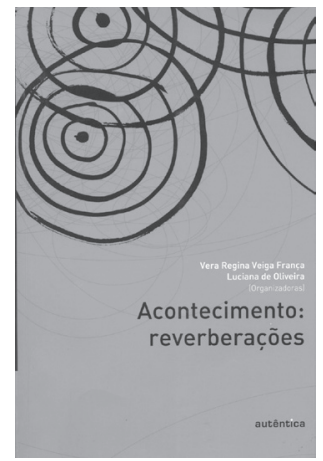

FRANÇA, Vera Regina Veiga; OLIVEIRA, Luciana de (Orgs.). Acontecimento: reverberações. Belo Horizonte: Autêntica, 2012. 336p.

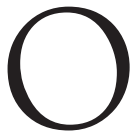

livro Acontecimento: reverberações (2012), organizado por Vera Regina Veiga França e Luciana de Oliveira, aponta um painel no qual o acontecimento é vislumbrado além do fato transcorrido na apreensão espaço-temporal; a análise do acontecimento como sinal conceitual se insere no debate da vida cotidiana, primordialmente. Em consonância à ideia do circunscrito experiencial, Louis Queré (A dupla vida do acontecimento: por um realismo pragmatista) mede o acontecimento na distinção entre a ocorrência eventual e a experiência da "conquista do passado" e localiza-o instrumentalizado na Comunicação, em meio à projeção memorial e a realidade do dia a dia.

Por isso mesmo, Vera Regina Veiga França (O acontecimento para além do acontecimento: uma ferramenta heurística) levanta a

* Doutor em Comunicação: Meios e processos audiovisuais pela ECA/USP. Mestre em Comunicação pela Unesp. Professor dos cursos de Comunicação Social da FIB - Faculdades Integradas de Bauru e da Unip - Campus Bauru - São Paulo, Brasil. E-mail: claudiocoracao@ig.com.br 
questão hermenêutica no centro de um debate epistemológico sobre o acontecimento, a remodelá-lo em outra chave, não menos instigante: como gerador de informações e como componente "perturbador dos quadros" de realidade. Isabel Babo-Lança (Acontecimento e memória) nota que o fazer-memória se amplia no Jornalismo (em seus mais variados canais e meios) como um estrato memorialístico específico ('o que se lembrar' e 'como se lembrar'). Existe, pois, um diálogo desses primeiros textos da obra com aquilo que Beatriz Bretas, logo em seguida (Propagação telemática dos acontecimentos e novos fazeres midiáticos), chama de apropriações telemáticas, no que se refere às fabricações simbólicas e midiáticas, em que o 11 de setembro talvez seja o grande emblema de certa materialização do acontecimento como íntimo da imagem, por meio da seguinte operação: recombinações sígnicas "-> experiências comunicativas - $>$ " padrões discursivos.

Ainda nesse tom, Alain Bovet (O acontecimento tomado pela palavra: um talk show sobre a morte de Osama Bin Laden) percebe a interação específica dos talk shows a fim de "desnudar" a lógica do "acontecimento planetário" teleguiado. Em complemento a essa versão, para Eduardo Duarte (A experiência estética pública na construção do cotidiano e seus acontecimentos) o acontecimento está tecido no cotidiano por partilhas do sensível (cf. Rancière), nos pertencimentos públicos da experiência individual envolvida no coletivo. A singularidade acontecimental é tão valorativa que no ensaio pessoal de Paulo Bernardo Vaz ( $\mathrm{Na}$ onda dos acontecimentos cotidianos) são apresentadas três aspirações da impressão e percepção vivida a uma premissa deleuziana (a conversação balizada no movimento biopolítico como acontecimento) quando Vaz anota, de maneira empírica e imersiva, a tragédia do Realengo pela e na mídia, bem como os sons e fúrias na ancoragem de Beethoven e Shakespeare em meio a cenários pós-modernos urbanos.

Há, portanto, uma síntese desenhada em Acontecimento: reverberações que alinha o acontecimento com os ditames da vida social, em seu processo de apreensão simbólica, informacional e política. Com isso, Joan Stavo-Debauge (A (in)experiência das vítimas e a 'mitologia do acontecimento') elenca os estágios da dor 
no mundo organizacional e na rigidez das narrativas e discursos jurídicos pelas arestas do que ele chama de "acontecimentos judiciais". Assim, a ideia da partilha do sensível é também utilizada por Ângela Cristina Salgueiro Marques (Acontecimento e criação de comunidades de partilha: o papel das ações comunicativas, estéticas e políticas), no que se refere às funções e afetos das atrizes e atores sociais na ampliação das ações comunicativas no espaço público (utilizando os conceitos de Habermas). A pressão em torno da esfera pública contemporânea é tão "esquizofrênica" na absorção dos eventos e das experiências que Laura Guimarães Corrêa e Miriam Chrystus (No adro da igreja: o assassinato de mulheres e a potencialização de acontecimentos entrelaçados) elucidam, a partir de coberturas jornalísticas do assassinato de mulheres, sintomas discursivos atrelados ao espaço não só público, mas também físico e midiático.

Por isso, a construção simbólica de "personagens midiáticas" se enreda no acontecimento regido pela narrativa institucionalizada da mídia, nos texto seguintes: Habibou Fofana (Norbert Zongo: das margens sociais ao coração do Estado - a constituição de um personagem público); João Freire Filho e Mayka Castellano (Eike Batista: o 'bilionário popstar': um estudo sobre a celebração midiática do empreendedorismo); Lígia Lana e Paula Guimarães Simões (Duas vinculações possíveis entre personagens públicos e acontecimentos: diferentes modos de atuação na vida pública).

Por fim, as marcas históricas em determinados contextos de urgência são sugeridas como "reconstruções do passado". Nesse sentido, estão os textos Os 30 anos do 11 de setembro de 1973 no Chile: comemoração de uma data, de Paola Diaz; Posts de uma revolução em declínio: Cuba na narrativa de Yoani Sánchez, de Márcio Serelle; e Acontecimentos violentos, ressentimento e as marcas de uma interpretação, de Elton Antunes. Os três, de certa maneira, estão intrinsecamente conectados aos demais, relacionados à temática das lutas discursivas. São eles: Os fundamentos sensíveis da experiência pública, de Louis Queré e Cédric Terzi; Acontecimento e resistência: mulheres contra a Aracruz, de Christa Berger; e Quando o agenciamento do sujeito acontece, de Marta Regina Maia. 